\title{
Analisis Kerusakan Tube Heat Exchanger Menggunakan Metode Remote Field Testing (RFT)
}

\author{
Dwita Suastiyanti ${ }^{1, a)}$, Yudha Fatanur ${ }^{2, b)}$, Pathya Rupajati ${ }^{3, c)}$ \\ 1,2,3 Program Studi Teknik Mesin Institut Teknologi Indonesia, \\ Jl. Raya Puspiptek Serpong, Tangerang Selatan-Banten, Indonesia, 15320 \\ a)dwita_suastiyanti@iti.ac.id, b) yudhafatanur03@gmail.com, ${ }^{\text {c) }}$ pathyarupajati@gmail.com
}

\begin{abstract}
Abstrak
Kegiatan pengolahan bahan kimia banyak melibatkan heat exchanger dan fluida service yang bersifat korosif. Seiring berjalannya waktu, heat exchanger tersebut akan mengalami korosi yang berakibat pada hasil akhir olahan bahan kima. Heat exchanger yang beberapa tubenya teridentifikasi terkorosi adalah heat exchanger unit EA-110 yang terdapat di PT. Chandra Asri Petrochemical. Pada studi kali ini, akan dilakukan penelitian yang bertujuan untuk menganalisis kerusakan pada bagian tube berupa adanya pengikisan diameter tube pada Heat Exchanger unit EA-110 di PT. Chandra Asri Petrochemical. Setelah itu, dilakukan proses pengujian pada tube heat exchanger unit EA-110 dengan material ASTM A 334 Gr. 1. Pada proses pengujian tersebut akan digunakan metode Non Destructive Test (NDT) Remote Field Testing (RFT), kemudian akan dilakukan pengamatan metalografi (mikro) dan pengujian kekerasan brinell untuk mengetahui kerusakan yang terjadi pada tube heat exchanger. Hasil terbesar pada pengujian kekerasan brinell adalah 146,149 HB dan hasil terkecil pada pengujian kekerasan brinell adalah 138,283 HB. Kedua hasil tersebut lebih rendah dari nilai kekerasan maksimum material dikarenakan waktu pemakaian tube yang sudah lama dan ditemukannya korosi seragam pada dinding tube yang disebabkan oleh deposit.
\end{abstract}

Kata kunci: heat exchanger, tube, korosi.

\begin{abstract}
The chemical processing has many activities involve the heat exchanger and fluid service that are corrosive. As time goes by, the heat exchanger will undergo corrosion resulting in the final result of the chemicals processed. Some of the heat exchangers that are unidentified are identified as the Heat Exchanger Unit EA-110 in PT. Chandra Asri Petrochemical. In this study, will conduct research aimed at analyzing the damage to the tube in the form of erosion of tube diameter in the Heat Exchanger unit EA-110 at PT Chandra Asri Petrochemical. After that, conducts the testing process on heat exchanger tube Unit EA-110 with material ASTM A 334 Gr.1. In the testing process will be used the Non-Destructive Test (NDT) Remote Field Testing (RFT) method. It will then be performed metallography observation (micro) and brinell hardness testing to find out the damage incurred in the heat exchanger tube. The highest results on brinell hardness testing are 146,149 HB and the lowest results on brinell hardness testing are 138,283 HB. Both of these results are lower than the maximum hardness value of the material due to the long tube usage time and the discovery of uniform corrosion on the tube wall caused by the deposit.
\end{abstract}

Keyword: heat exchanger, tube, corrosion.

\section{PENDAHULUAN}

Heat exchanger akan mengalami korosi yang berakibat pada hasil akhir olahan bahan kima. Korosi tersebut dikarenakan tube heat exchanger yang telah lama beroperasi ditambah dengan metode pembersihan tube yang kurang optimal menyebabkan terjadinya korosi di seluruh permukaan dalam pipa. Oleh karena itu dibutuhkan sistem perawatan yang baik agar heat exchanger dapat terus bekerja secara maksimal.

Kerusakan tube drain superheater tidak dipengaruhi oleh pengoperasian kerja apabila dilihat dari permukaan dalamnya, akan tetapi disebabkan oleh penurunan ketebalan secara progresif akibat korosi yang dimulai dari permukaan luar dan korosi terjadi karena permukaan luar kontak dengan air sebagai media korosif yang dapat berasal dari luar dan dari panas yang mengembun pada permukaan tube drain superheater [1].

Bahwa tube heat exchanger mengalami putus karena serangan korosi sumur (pitting corrosion) pada permukaan dalam dan luar tube. Terjadinya serangan korosi sumur (pitting corrosion) karena pada permukaan dalam dan luar tube terlapisi oleh deposit yang cukup tebal dan mengandung unsur-unsur Sulphur (S) dan Chlor $(\mathrm{Cl})$ yang dapat memicu timbulnya serangan korosi sumuran (pitting corrosion), hingga tube mengalami penipisan dimana-mana. Selain itu dengan adanya deposit pada permukaan dalam dan luar tube dapat menghambat perpindahan panas antara gas yang terbakar untuk 
memanasi pipa dan fluida air yang mengalir di dalam pipa [2].

Terjadi pembentukan lapisan $\mathrm{Fe}_{2} \mathrm{O}_{3}$ pada permukaan dalam dan lapisan $\mathrm{Fe}_{3} \mathrm{O}_{4}$ pada permukaan luar bend tube preheater, baik secara pengujian XRD maupun pengujian microstructure. Pembentukan lapisan $\mathrm{Fe}_{2} \mathrm{O}_{3}$ yang terjadi karena adanya reaksi antara logam $\mathrm{Fe}$ dengan air yang mengalir dalam bend tube preheater. Lapisan $\mathrm{Fe}_{3} \mathrm{O}_{4}$ yang terjadi karena adanya reaksi antara logam $\mathrm{Fe}$ dengan gas sisa pembuangan pembakaran turbin gas [3].

Penyebab utama penurunan performa heat exchanger bukan disebabkan oleh penipisan ketebalan shell maupun penurunan fluida servisnya (laju aliran dan temperatur fluida) tetapi dikarenakan perpindahan panas yang kurang sempurna karena adanya kotoran yang menempel pada tube. Untuk mengembalikan performa heat exchanger direkomendasikan perbaikan berupa pembersihan setiap dua tahun sekali pada seluruh permukaan tube baik bagian luar maupun bagian dalam dengan menggunakan water jet dengan campuran cairan chemical [4].

\section{LANDASAN TEORI}

\section{A. Alat Penukar Kalor (Heat Exchanger)}

Alat penukar kalor (heat exchanger) adalah suatu alat yang digunakan untuk memindahkan panas antara dua buah fluida atau lebih yang memiliki perbedaan temperatur yaitu fluida yang bertemperatur tinggi ke fluida yang bertemperatur rendah. Perpindahan panas tersebut baik secara langsung maupun secara tidak langsung. Pada alat penukar kalor yang langsung, fluida yang panas akan bercampur secara langsung dengan fluida dingin (tanpa adanya pemisah) dalam suatu bejana atau ruangan tertentu. Sedangkan pada alat penukar kalor yang tidak langsung, fluida panas tidak berhubungan langsung dengan fluida dingin. Jadi proses perpindahan panas itu mempunyai media perantara, seperti pipa, pelat atau peralatan jenis lainnnya.

Dalam penerapannya, heat exchanger digunakan diberbagai sektor mulai dari pemanas maupun pendingin. Biasanya, media pemanas yang digunakan uap panas (super heated steam) dan air sebagai pendingin (cooling water) [2]. Perpindahan panas yang terjadi pada heat exchanger biasanya merupakan perpindahan kalor secara konveksi antara fluida satu dengan fluida yang lain dan perpindahan kalor secara konduksi yang terjadi pada dinding yang memisahkan kedua fluida.

Tujuan perpindahan panas tersebut di dalam proses industri diantaranya adalah:

a) Memanaskan atau mendinginkan fluida hingga mencapai temperature tertentu yang dapat memenuhi persyaratan untuk proses selanjutnya, seperti pemanasan reaktan atau pendinginan produk dan lain-lain.

b) Mengubah keadaan (fase) fluida: destilasi, evaporasi, kondensasi dan lain-lain [5].

\section{B. Jenis-jenis Heat Exchanger}

Jenis heat exchanger yang terdapat pada dunia industri dapat dibedakan menjadi:

\section{Heat Exchanger Shell and Tube}

Alat ini terdiri dari sebuah shell (tabung/silinder besar) dimana didalamnya terdapat suatu bundle (berkas) pipa dengan diameter yang relatif kecil. Satu jenis fluida mengalir didalam pipa-pipa sedangkan fluida lainnya mengalir dibagian luar pipa tetapi masih didalam shell.

Tipe shel and tube sendiri memiliki berbagai konfigurasi berdasarkan perlintasan (passes) shell maupun tubes [5]. Heat exchanger shell and tube dapat dilihat pada Gambar 1.

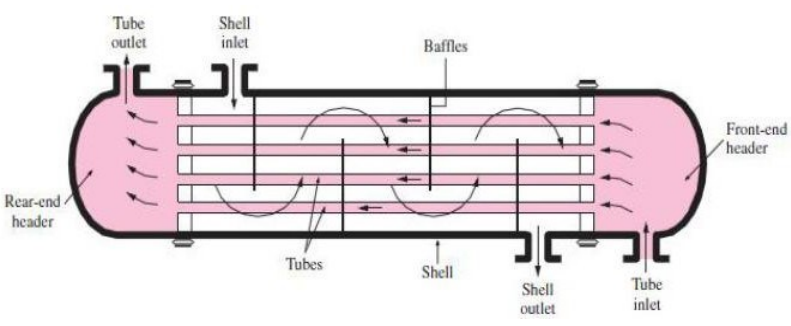

Gambar 1. Heat exchanger shell and tube

\section{Heat Exchanger Double Pipe (Pipa Ganda)}

Alat penukar panas pipa rangkap terdiri dari dua pipa logam standart yang dikedua ujungnya dilas menjadi satu atau dihubungkan dengan kotak penyekat. Fluida yang satu mengalir di dalam pipa, sedangkan fluida kedua mengalir di dalam ruang anulus antara pipa luar dengan pipa dalam. Heat exchanger double pipe dapat dilihat pada Gambar 2.

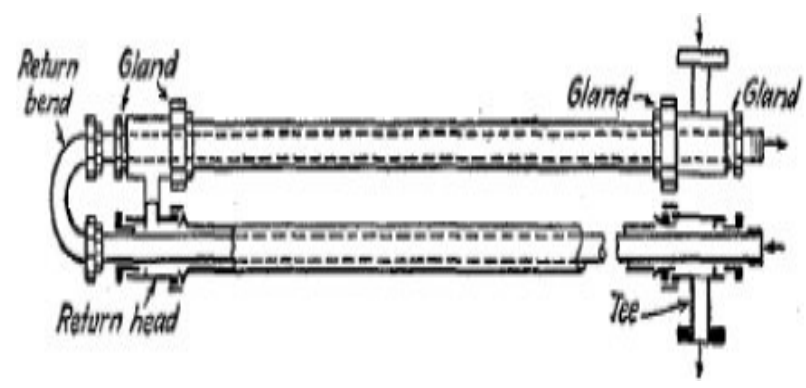

Gambar 2. Heat exchanger double pipe (pipa ganda)

\section{Heat Exchanger Coil Pipe}

Heat Exchanger ini mempunyai pipa berbentuk koil yang dibenamkan didalam sebuah box berisi air dingin yang mengalir atau yang disemprotkan untuk mendinginkan fluida panas yang mengalir di dalam pipa. Jenis ini disebut juga sebagai box cooler jenis ini biasanya digunakan untuk pemindahan kalor yang relatif kecil dan fluida yang didalam shell yang akan diproses lanjut. Heat exhanger coil pipe dapat dilihat pada Gambar 3. 


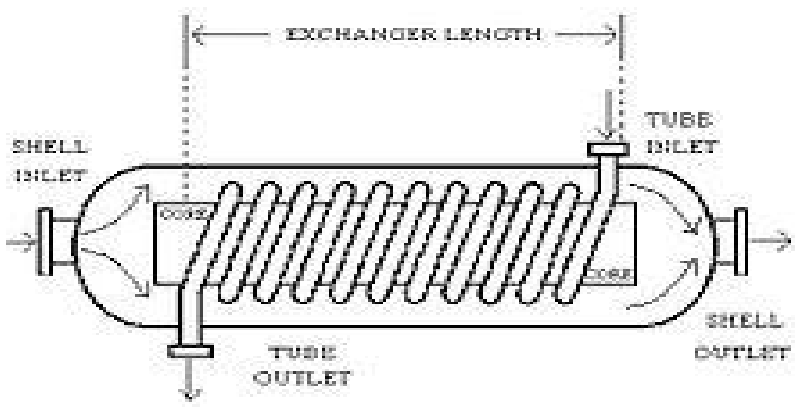

Gambar 3. Heat exchanger coil pipe

4. Heat Exchanger Pipa Terbuka (Open Tube Section) Pada heat exchanger ini pipa-pipa tidak ditempatkan lagi didalam shell, tetapi dibiarkan di udara. Pendinginan dilakukan dengan mengalirkan air atau udara pada bagian pipa. Untuk pendinginan dengan udara biasanya bagian luar pipa diberi sirip-sirip untuk memperluas permukaan perpindahan panas. Heat exchanger pipa terbuka dapat dilihat pada Gambar 4.

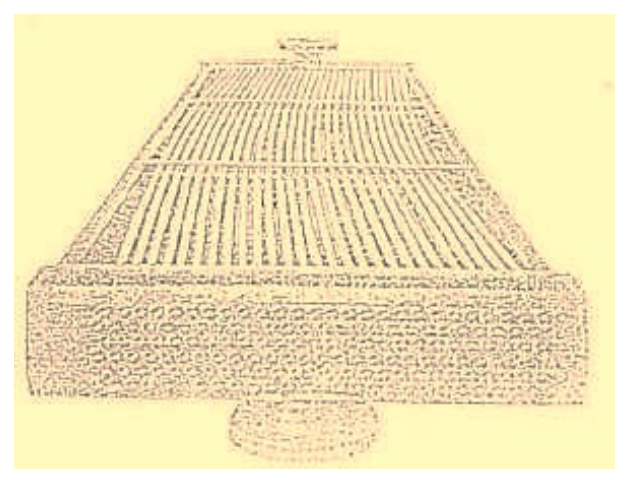

Gambar 4. Heat exchanger pipa terbuka (open tube section)

\section{Plate Heat Exchanger}

Merupakan salah satu jenis alat penukar panas yang terdiri atas paket pelat- pelat tegak lurus bergelombang atau dengan profil lain, yang dipisahkan antara satu dengan lainnya oleh sekat-sekat lunak. Pelat-pelat ini dipersatukan oleh suatu perangkat penekan dan jarak antara pelat-pelat ditentukan oleh sekat-sekat tersebut. Plate heat exchanger dapat dilihat pada Gambar 5.

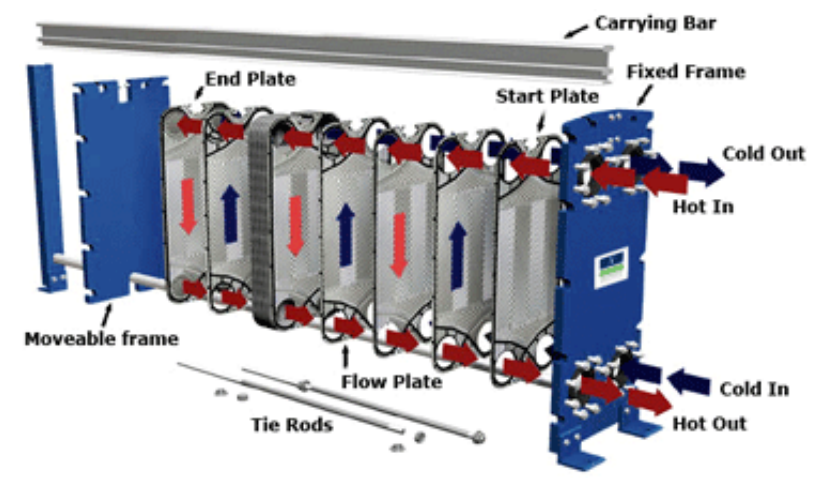

Gambar 5. Plate heat exchanger
C. Komponen Pada Heat Exchanger Shell and Tube

Berikut adalah beberapa macam komponenkomponen yang terdapat dalam heat exchanger tipe shell and tube, yaitu :

\section{Shell}

Shell merupakan badan dari heat exchanger, dimana terdapat tube bundle. Antara shell and tube bundle terdapat fluida yang menerima atau melepaskan panas. Yang dimaksud dengan lintasan shell adalah lintasan yang dilakukan oleh fluida yang mengalir ke dalam melalui saluran masuk (inlet nozzle) dan mengelilingi tube kemudian keluar melalui saluran keluar (outlet nozzle). Konstruksi shell sangat ditentukan oleh keadaan tubes yang akan ditempatkan didalamnya. Shell ini dapat dibuat dari pipa yang berukuran besar atau pelat logam yang dirol.

\section{Tube}

Tube atau pipa merupakan bidang pemisah antara kedua jenis fluida yang mengalir didalamnya dan sekaligus sebagai bidang perpindahan panas. Selain itu bahan pipa tidak mudah terkorosi oleh fluida kerja. Bahan tube dapat diubah dari berbagai jenis logam, seperti besi, tembaga, perunggu, tembaga-nikel, aluminium perunggu, aluminium dan stainless steel. Diameter dalam tube merupakan diameter dalam actual dalam ukuran inch dengan toleransi yang sangat cepat. Ketebalan dan bahan pipa harus dipilih pada tekanan operasi fluida kerjanya. Ukuran ketebalan pipa berbedabeda dan dinyatakan dalam bilangan yang disebut Birmingham Wire Gage (BWG).

\section{Sekat (Baffle)}

Baffle adalah bagian integral dari desain heat exchanger tipe shell and tube. Baffle dirancang untuk mendukung tube bundle dan mengarahkan aliran cairan untuk efisiensi maksimum [6]. Desain dan toleransi baffle untuk heat exchanger dibahsa dalam Tubular Exchanger Manufacturers Assosiation (TEMA). Adapun fungsi dari pemasangan sekat (baffle) pada heat exchanger ini antara lain adalah untuk:

- Sebagai penahan dari tube bundle.

- Untuk mengurangi atau menambah terjadinya getaran.

- Sebagai alat untuk mengarahkan aliran fluida yang berada di dalam tubes.

\section{Pass Divider}

Komponen ini berupa plat yang dipasang di dalam channels yang berfungsi untuk membagi aliran fluida tube bila diinginkan jumlah tube pass lebih dari satu.

\section{Tube Sheet}

Tube sheet adalah tempat untuk merangkai ujungujung tube sehingga menjadi satu yang disebut tube bundle. Heat Exchanger dengan tube lurus pada umumnya menggunakan 2 buah tube sheet. Sedangkan pada tube tipe U menggunakan satu buah tube sheet yang berfungsi untuk menyatukan tube-tube menjadi tube bundle dan sebagai pemisah antara tube side dengan shell 
side. Tube sheet merupakan bagian yang penting pada penukar kalor. Bagian ini merupakan tempat disatukannya pipa-pipa pada bagian ujungnya. Tube sheet ini dibuat tebal dan pipa harus terpasang rapat tanpa bocor pada tube sheet. Dengan konstruksi fluida yang mengalir pada badan shell tidak akan tercampur dengan fluida yang mengalir didalam tube. Penyambungan antara tube sheet dengan pipa merupakan hal yang paling penting untuk diperhatikan, karena segala kegagalan penyambungan ini akan menyebabkan kebocoran dan pencampuran kedua fluida di dalam penukar kalor.

\section{Korosi yang Terjadi Pada Heat Exchanger}

Definisi umum tentang korosi dapat disingkat seabgai "kerusakan atau degradasi" suatu material yang umumnya adalah logam akibat suatu proses reaksi dengan lingkungan. Dalam pembicaraan sehari-hari, korosi lebih dikenal dengan istilah karat atau pengkaratan [7]. Berikut adalah beberapa korosi yang terjadi pada heat exchanger, antara lain:

\section{General Korosi Atmosfer (General corrosion)}

Korosi secara kimiawi korosi adalah reaksi pelarutan (dissolution) logam menjadi ion pada permukaan logam yang berinteraksi dengan lingkungan yang dapat bersifat asam atau basa melalui reaksi elektrokimia. Logam tersebut memiliki ion positif dan negatif, yang apabila berhubungan dengan udara maka akan membentuk senyawa baru.

\section{Korosi Galvanis}

Korosi galvanis berprinsip reaksi sebagaimana halnya sel galvanis. Korosi galvanis merupakan proses pengkorosian elektrokimiawi jika dua macam logam yang berbeda potensial dihubungkan langsung di dalam elektrolit yang sama.

\section{Korosi Erosi (Errosion corrosion)}

Erosi adalah kerusakan permukaan metal yang disebabkan oleh aliran fluida yang sangat deras. aliran fluida di permukaan logam yang sebetulnya halus. Adanya celah yang memungkinkan fluida mengalir di luar aliran utama.

\section{Korosi Sumuran (Pitting corrosion)}

Bentuknya ada yang merata di seluruh permukaan metal, ada yang terisolir (isolated), namun keseluruhannya berada dalam lingkungan yang cair atau basah, hal ini dikarenakan sumuran tersebut sebagai akibat proses elektrokimia yang terkonsentrasi pada suatu lokasi secara berkesinambungan.

\section{Korosi Kavitasi}

Korosi ini disebabkan karena tingginya kecepatan cairan menciptakan daerah-daerah bertekanan tinggi dan rendah secara berulang-ulang pada permukaan peralatan dimana cairan tersebut mengalir, maka terjadilah gelembung-gelembung uap cairan pada permukaan tersebut.

\section{E. Pengujian Non-Destructive}

Pengujian Non-Destructive (NDT) adalah proses pengujian suatu material untuk mengetahui cacat, retak, atau discontinuitas lain pada material tanpa merusak benda yang kita tes. Pada dasarnya, tes ini dilakukan untuk menjamin bahwa material yang kita gunakan masih aman dan tidak melewatidamage tolerance. Pengujian Non-Destructive dibagi menjadi beberapa macam, yaitu:

\section{Uji Visual (Visual Inspection)}

Biasanya metode ini menjadi langkah yang pertama kali diambil dalam NDT. Metode ini bertujuan untuk menemukan cacat atau retak permukaan dan korosi. Dengan bantuan visual optical, sehingga crack yang berada di permukaan material diketahui.

\section{Uji Hypereutectoid}

Metode Hyper-eutectoid merupakan pengujian untuk mengetahui cacat permukaan dan permukaan bawah suatu komponen dari bahan-bahanferromagnetik. Dengan menggunakan prinsip magnetisasi, bahan yang akan diuji akan dialiri arus listrik. Adanya cacat yang tegak lurus pada medan magnet akan menyebabkan kebocoran medan magnet. Kebocoran ini mengindikasikan adanya cacat pada material.

\section{Uji Cairan Penetran (Liquid penetrant)}

Metode ini sangat sederhana, dimana cairan warna terang disemprot kepada benda uji untuk mengetahui cacatnya. Tujuannya adalah mengetahui keretakan atau kerusakan pada material solid. Caranya, pertama menggunakan cairan penetran yang memiliki viskositas rendah dan daya penetrasi tinggi, kemudian dibersihkan dengan cairan pembersih, setelah itu diaplikasikan cairan developer yang tujuannya memunculkan cairan penetran.

\section{Eddy Current Test}

Pengujian ini memanfaatkan prinsip elektromagnet. Prinsipnya elektromagnet dialirkan pada komponen untuk membangkitkan medan magnet pada komponen. Jika medan magnet dikenai pada logam, yang akan diinspeksi maka akan membangkitkan arus eddy. Arus eddy kemudian akan membangkitkan medan magnet pada kumparan yang mengindikasikan ada cacat.

\section{Ultrasonic Inspection}

Pengujian ini mempunyai prinsip kerja yaitu dimana gelombang ultrasonic ini disorotkan ke permukaan bidang yang sedang di uji dengan garis lurus pada kecepatan konstan, kemudian gelombang tersebut dipantulkan lagi dari permukaan atau cacat benda uji tersebut. Yang diperoleh gelombang suara tersebut akan ditampilkan pada layar monitor berupa tampilan pulsa untuk mendeteksi tebal serta cacat atau tidaknya benda uji tersebut.

\section{Radiographic Test}

Radiographic test adalah suatu pengujian dengan menggunakan emisi spektografik dari radiasi sinar $\mathrm{X}$ yang memanfaatkan sinar $\mathrm{X}$ yang mampu menembus 
logam dan merefleksikannya dengan menghasilkan emisi radiasi dalam bentuk spektografi yang dapat menunjukkan cacat pada logam. Prosesnya dengan meradiasikan sinar $\mathrm{X}$ ke sebuah spesimen dan melihat hasilnya dalam gambaran emisi spektografi dibalik spesimen.

\section{F. Remote Field Testing (RFT)}

Pengujian remote field testing pertama kali dicatat pada tahun 1940-an dan dipatenkan oleh W.R. Maclean pada tahun 1951. Pada akhir 1950-an, Thomas R. Schmidt secara mandiri menemukan kembali teknik tersebut dengan mengembangkan alat untuk menguji selubung sumur minyak. Schmidt mempelopori pengembangan teknik dan menamakannya menjadi pengujian remote field eddy current testing. Teknik yang digunakan oleh industri sekarang disebut sebagai pengujian remote field testing. Beberapa produsen alat uji mengakui nilai teknik elektromagnetik yang tidak merusak ini untuk pengujian tabung heat exchanger dan mulai membuat instrumen pengujian remote field testing pada tahun 1985 [8]. Berikut adalah bentuk dari alat pada pengujian RFT yang terdapat pada Gambar 6.

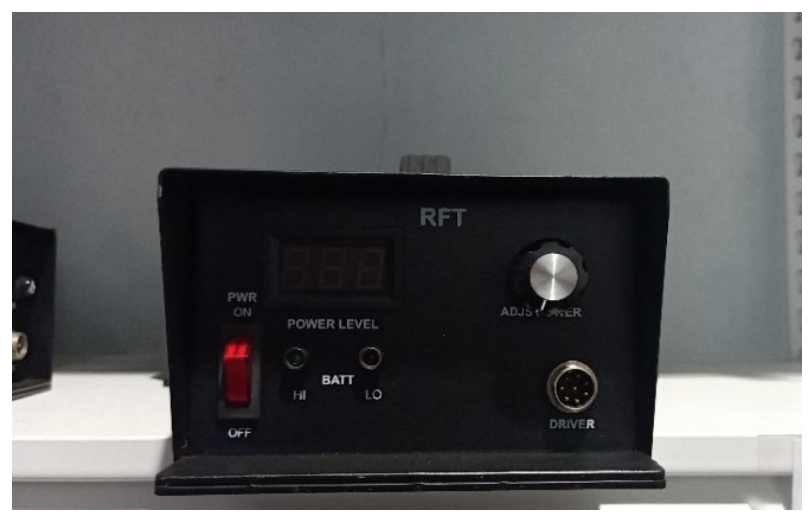

Gambar 6. Remote field testing

Pengujian remote field testing dapat digunakan untuk semua spesifikasi material baja karbon konvesional, diameter dan ketebalan dinding. Kecepatan uji bisa hingga 60 kaki per menit tergantung pada ketebalan dinding dan frekuensi uji. Pengujian remote field testing adalah teknik non-kontak. Probe pada pengujian ini memiliki gesekan minimal dengan tabung atau dinding pipa dan tidak memerlukan couplant. Probe pada RFT menggunakan satu atau beberapa kumparan pemancar yang diposisikan dua diameter tabung terpisah dari kumparan penerima. Medan magnet yang diciptakan oleh koil pemancar bergerak keluar-masuk dari dinding tabung, secara radial dan aksial menuju penerima. Medan magnet harus melewati dinding tabung lagi untuk mencapai penerima. Ini disebut melalui transmisi dan inilah yang mendefinisikan RFT. Melalui transmisi memungkinkan cacat eksternal dan internal terdeteksi dengan sensitivitas yang sama.

Pengujian remote field testing dapat mendeteksi diskontinuitas permukaan dalam dan luar dengan sensitivitas yang sama, tetapi dalam kebanyakan kasus tidak dapat membedakan keduanya tanpa menggunakan kumparan medan dekat.

Nilai fill factor (faktor pengisian) yang besar tidak terlalu berpengaruh pada pengujian RFT ini, berbeda dengan pengujian non destructive lainnya untuk pengaplikasian yang sama. Data hasil pengujian RFT ini direkam di dalam memori komputer atau hardisk, selama proses perekaman data pada pengujian RFT ini menampilkan diagram fasa besarnya amplitudo pada monitor alat yang digunakan secara aktual (real time). Data tersebut dapat ditampilkan kembali, dianalisis dan digunakan dalam persiapan laporan akhir.

Remote Field Testing (RFT) memiliki beberapa keunggulan dibandingkan teknik pengujian elektromagnetik lainnya:

- Cocok untuk bahan feromagnetik.

- Sensitivitas yang sama pada permukaan bagian dalam dan luar.

- Sangat sensitif terhadap variasi ketebalan dinding.

- Dapat digunakan dengan faktor pengisian yang lebih rendah daripada ECT (Eddy Current Testing).

\section{G. Pengamatan Metalografi}

Merupakan ilmu yang mempelajari karakteristik mikrostruktur dan makrostruktur suatu logam, paduan logam dan material lainnya serta hubungannya dengan sifat-sifat material, atau biasa juga dikatakan suatu proses untuk mengukur suatu material baik secara kualitatif maupun kuantitatif berdasarkan informasi-informasi yang didapatkan dari material yang diamati. Struktur mikro yang kecil akan membuat kekerasan logam akan meningkat. Dan juga sebaliknya, struktur mikro yang besar akan membuat logam menjadi ulet atau kekerasannya menurun. Struktur mikro itu sendiri dipengaruhi oleh komposisi kimia dari logam atau paduan logam tersebut serta proses yang dialaminya.

Metalografi bertujuan untuk mendapatkan struktur makro dan mikro suatu logam sehingga dapat dianalisis sifat mekanik dari logam tersebut. Pengamatan metalografi dibagi menjadi dua, yaitu:

1. Metalografi makro, yaitu penyelidikan struktur logam dengan pembesaran $10 \pm 100$ kali.

2. Metalografi mikro, yaitu penyelidikan struktur logam dengan pembesaran 1000 kali.

\section{H. Pengujian Kekerasan Metode Brinell}

Pengujian kekerasan dengan metode Brinell bertujuan untuk menentukan kekerasan suatu material dalam bentuk daya tahan material terhadap bola baja (indentor) yang ditekankan pada permukaan material uji tersebut (spesimen). Idealnya, pengujian brinell diperuntukan untuk material yang memiliki permukaan yang kasar dengan uji kekuatan berkisar 500-3000 kgf. Indentor (bola baja) biasanya telah dikeraskan dan diplating ataupun terbuat dari bahan karbida tungsten. Prinsip dari pengujian kekerasan ini dengan menekan indentor selama 30 detik. Kemudian diameter hasil identansi diukur dengan menggunakan mikroskop optik. Diameter harus dihitung dua kali pada sudut tegak lurus yang berbeda, kemudian dirata-ratakan. 


\section{METODE PENELITIAN}

Metode penelitian dilakukan berdasarkan diagram alir perancangan yang ditunjukkan pada Gambar 7 .

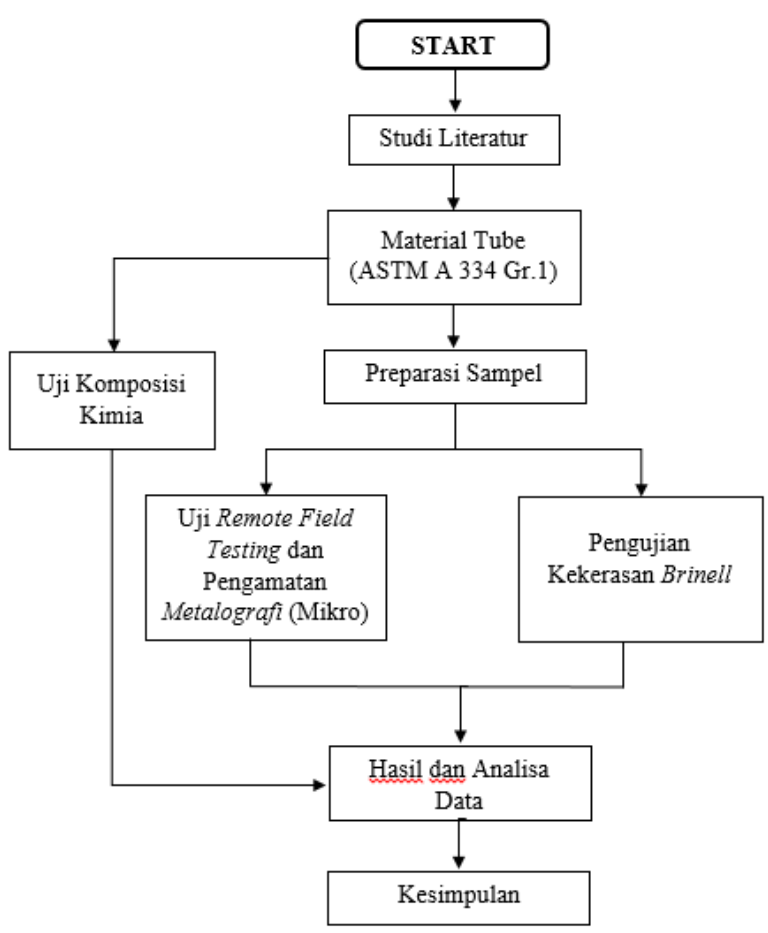

Gambar 7. Diagram alir perancangan

\section{HASIL DAN PEMBAHASAN}

A. Hasil Pemeriksaan Remote Field Testing (RFT)

Metode pengujian dilakukan mengikuti standar ASME Section V - Article 17. Tube heat exchanger diperiksa dengan membandingkan kurva dalam instrumen yang telah dikalibrasi dengan Tube Standar Kalibrasi. Tube standar kalibrasi dibuat dari material dan dimensional yang sama dengan tube yang akan diperiksa $[9,10]$.

Dalam tube standar atau kalibrasi dibuat cacat-cacat buatan untuk dipergunakan sebagai acuan klasifikasi rentang cacat dalam warna-warna tertentu seperti ditunjukkan pada Tabel 1.

Tabel 1. Klasifikasi rentang cacat

\begin{tabular}{cc}
\hline $\begin{array}{c}\text { Defect } \\
\text { Class }\end{array}$ & $\begin{array}{c}\text { Range of Defect } \\
\text { (Percentage of Wall } \\
\text { Thickness Loss) }\end{array}$ \\
\hline 1 & $0 \%-20 \%$ \\
2 & $21 \%-40 \%$ \\
3 & $41 \%-60 \%$ \\
4 & $61 \%-100 \%$ \\
\hline
\end{tabular}

Heat exchanger item EA-110 ini memiliki spesifikasi sesuai dengan kegunaan dan fungsinya. Berikut adalah penjelasan tentang spesifikasi heat exchanger item EA110 yang tertera pada Tabel 2 .
Tabel 2. Hasil pemeriksaan RFT

\begin{tabular}{|c|c|c|c|c|c|c|c|}
\hline No & $\begin{array}{l}\text { Equipment } \\
\text { Name }\end{array}$ & Location & $\begin{array}{c}\text { Tube } \\
\text { Material } \\
\text { Spec. }\end{array}$ & $\begin{array}{l}\text { O.D. } \\
(\mathrm{mm})\end{array}$ & $\begin{array}{c}\text { Thickness } \\
\text { (mm) }\end{array}$ & $\begin{array}{c}\text { Tube } \\
\text { Length } \\
(\mathrm{mm})\end{array}$ & $\begin{array}{l}\text { Total } \\
\text { Tube }\end{array}$ \\
\hline 1 & $\begin{array}{c}\text { Tube Heat } \\
\text { Exchanger } \\
\text { EA-110 }\end{array}$ & $\begin{array}{c}\text { Ethylene } \\
\text { Plant }\end{array}$ & $\begin{array}{l}\text { A } 334 \\
\text { Gr. } 1\end{array}$ & 50,8 & 4 & 5000 & 322 \\
\hline
\end{tabular}

Setelah mengetahui spesifikasi dari heat exchanger dan berbagai macam klasifikasi yang ditentukan, maka selanjutnya dilakukan pemeriksaan tube secara keseluruhan. Lalu diperoleh data-data hasil pemeriksaan tube pada heat exchanger EA-110. Berikut adalah datadata dari hasil pemeriksaan tube heat exchanger EA-110 dengan menggunakan metode remote field testing (RFT).

Tabel 3. Hasil pemeriksaan RFT

\begin{tabular}{cccccccc}
\hline & & \multicolumn{5}{c}{ Defect Classifications } & Probe \\
\cline { 3 - 6 } Equipment & Inspected & & \\
Name & Tube & $0 \%-$ & $21 \%$ & $41 \%-$ & $61 \%-$ & Stuck $/$ & Old \\
& & $20 \%$ & $40 \%$ & $60 \%$ & $100 \%$ & No & Plug \\
Access & \\
\hline Tube Heat & & & & & & & \\
Exchanger & 322 & 285 & 24 & 13 & 0 & 0 & 0 \\
EA-110 & & & & & & & \\
\hline
\end{tabular}

Berdasarkan data-data pada Tabel 2 terdapat 13 tube (4.04\%) yang memiliki indikasi pengurangan ketebalan dinding tube antara $41 \%$ s.d. $60 \%$ (tube wall loss $41 \%$ $60 \%)$. Terdapat pula 24 tube $(7.45 \%)$ dengan indikasi pengurangan ketebalan dinding tube antara $21 \%$ s.d. $40 \%$ (tube wall loss 21\% - 40\%). Sementara, 285 tube lainnya $(88.51 \%)$ rata-rata kondisinya masih bagus atau maksimum hanya mengalami pengurangan ketebalan dinding tube kurang dari $20 \%$ (tube wall loss $\leq 20 \%$ ). Setelah itu, semua data yang diperoleh akan dijelaskan dengan membandingkan hasil kalibrasi pada tube dan hasil pemeriksaan pada tube.

- Hasil pemeriksaan cacat klasifikasi 1

Hasil ini tegolong ke dalam kategori aman dan dapat digunakan dengan semestinya atau tidak bermasalah pada dinding tube nya. Karena pada tube tersebutt hanya mengalami pengikisan sebesar $0-20 \%$ dari tebal dinding tube. Hasil pemeriksaan RFT dengan rentang cacat 0 $20 \%$ dapat dilihat pada Gambar 8 .

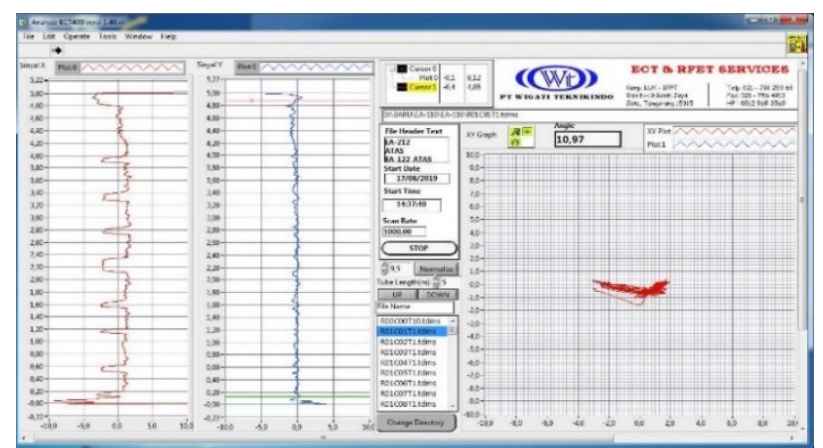

Gambar 8. Hasil pemeriksaan remote field testing dengan rentang cacat $0-20 \%$ 
Dari hasil analisis pada diagram garis tersebut didapatkan bahwa keadaan tube heat exchanger pada row 1 kolom 1 tidak terdapat indikasi yang mencolok atau melebihi $20 \%$ pengurangan ketebalan dinding tube dari ketebalan aslinya. Dengan begitu dapat dikatakan bahwa tube tersebut masih aman dan masih layak digunakan untuk kegiatan produksi dalam waktu beberapa tahun lagi.

- Hasil pemeriksaan cacat klasifikasi 2

Hasil pemeriksaan dengan cacat klasifikasi 2 adalah tube yang mengalami pengurangan ketebalan dinding sebesar 21-40\%. Hal tersebut diperoleh dengan membandingkan hasil kalibrasi dengan hasil pemeriksaannya. Biasanya tube dengan kondisi seperti ini masih bisa digunkan, hanya saja dengan jangka waktu yang tidak lama lagi. Contoh perbandingan hasil kalibrasi dengan hasil pemeriksaan pada tube dapat dilihat pada Gambar 9 .

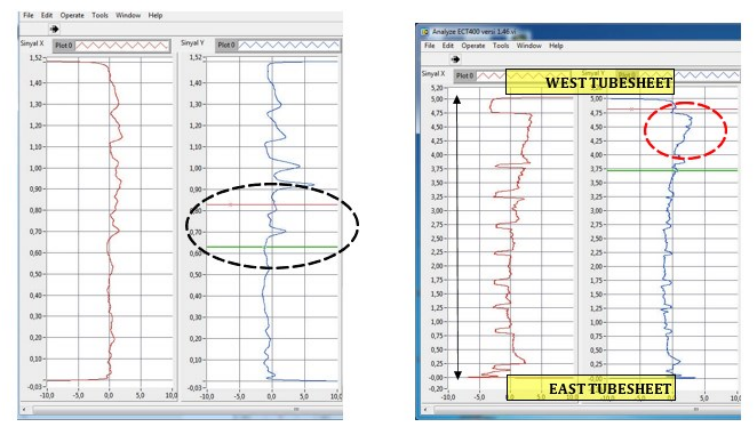

Gambar 9. Perbandingan antara hasil kalibrasi rentang cacat sebesar 30\% dengan hasil pemeriksaan pada tube

Dari hasil analisis perbandingan pada diagram garis tersebut didapatkan bahwa keadaan tube heat exchanger pada row 2 kolom 2 terdapat indikasi bahwa tube tersebut mengalami pengurangan ketebalan dinding tube sebesar 21-40\%. Indikasi tersebut ditandai dengan lingkaran berwarna merah yang terdapat pada Gambar 8. Tube tersebut masih sangat memungkinkan untuk digunakan dalam kegiatan produksi, selama belum mengakibatkan penurunan performa dan kinerja dari heat exchanger.

Dengan membandingkan hasil kalibrasi dengan hasil pemeriksaan aktual, kita bisa melihat bahwa ada persamaan bentuk grafik garis antara hasil tube kalibrasi dengan hasil pemeriksaan tube aktual. Pada hasil kalibrasi ditentukan bahwa indikasi pengurangan ketebalan dinding tube tersebut sebesar 30\% sedangkan pada pemeriksaan secara aktual ditentukan pengurangan ketebalan dinding tube sebesar 21\%-40\%. Hasil dari pemeriksaan aktual tersebut bisa kita simpulkan bahwa tube tersebut mengalami pengurangan ketebalan dinding dengan rentang sebesar $21-40 \%$.

- Hasil pemeriksaan cacat klasifikasi 3

Hasil pemeriksaan dengan cacat klasifikasi 3 adalah tube yang mengalami pengurangan ketebalan dinding sebesar 41-60\%. Hasil tersebut bisa diketahui dengan mebandingkan hasil kalibrasi dengan hasil pemeriksaan pada tube. Biasanya tube dengan kondisi seperti ini sudah rawan dan sebaiknya ditutup atau diganti dengan tube yang baru. Contoh perbandingan hasil kalibrasi dengan hasil pemeriksaan pada tube dapat dilihat pada Gambar 10.
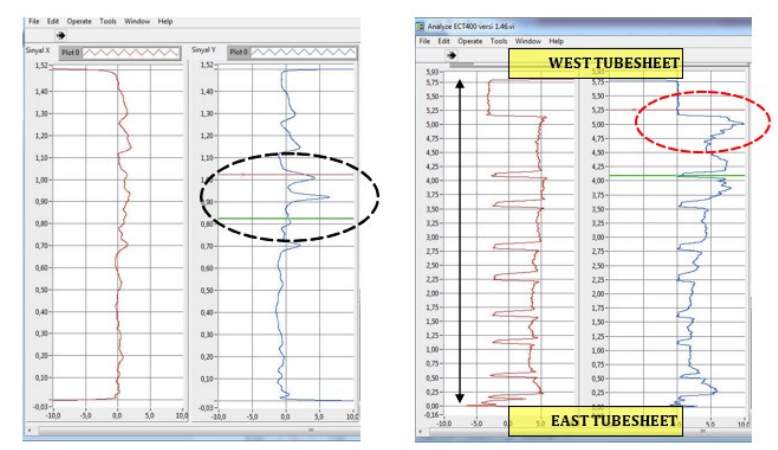

Gambar 10. Perbandingan antara hasil kalibrasi rentang cacat sebesar $60 \%$ dengan hasil pemeriksaan pada tube

Dari hasil analisis perbandingan pada diagram garis tersebut didapatkan bahwa keadaan tube heat exchanger pada row 1 kolom 5 terdapat indikasi bahwa tube tersebut mengalami pengurangan ketebalan dinding tube sebesar 41-60\%. Indikasi tersebut ditandai dengan lingkaran berwarna merah yang terdapat pada Gambar 9. Kondisi tube tersebut mengalami pengurangan ketebalan dinding yang parah karena sudah setengah dari ketebalan dinding awalnya terkikis. Tube dengan kondisi seperti ini sangat tidak dianjurkan untuk tetap digunakan karena akan menggangu kinerja dan performa dari heat exchanger yang akan berpengaruh kepada kualitas hasil produksi. Oleh karena itu, tube dengan kondisi seperti ini akan direkomendasikan untuk ditutup atau disumbat (plug), atau dengan merekomendasikan penggantian tube dengan tube yang baru untuk menjaga kinerja dan performa heat exchanger agar tidak mempengaruhi hasil produksi

Dengan membandingkan hasil kalibrasi dengan hasil pemeriksaan aktual, kita bisa melihat bahwa ada persamaan bentuk grafik garis antara hasil tube kalibrasi dengan hasil pemeriksaan tube aktual. Hasil pada pemeriksaan tube kalibrasi menunjukkan pengurangan ketebalan dinding sebesar $60 \%$ dan pada hasil pemeriksaan tube secara aktual menunjukkan pengurangan ketebalan dinding sebesar 41\%-60\%. Dari data tersebut bisa kita simpulkan bahwa tube tersebut termasuk ke dalam klasifikasi pengurangan ketebalan dinding dengan rentang sebesar 41-60\%.

- Hasil pemeriksaan keseluruhan

Berikut adalah hasil pemeriksaan secara keseluruhan tube heat exchanger unit EA-110 berdasarkan beberapa klasifikasi cacatnya melalui warna-warna yang berbeda yang akan ditunjukkan pada Gambar 11 . 


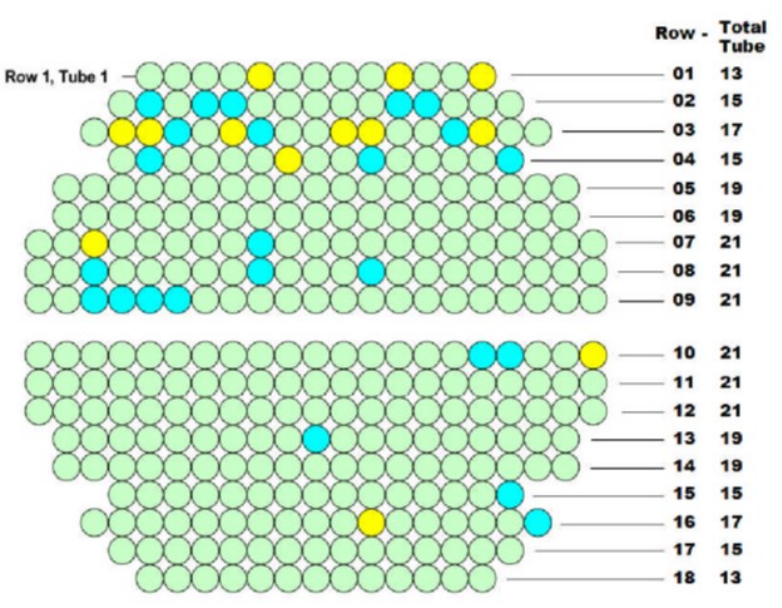

Gambar 11. Hasil pemeriksaan keseluruhan pada tube

Dari Gambar 11 dapat disimpulkan bahwa kondisi dari heat exchanger tersebut masih layak dan efisien dalam mengolah hasil produksi tanpa menggangu kualitas produk. Hanya saja ada beberapa indikasi pada tube yang sudah mengalami pengurangan ketebalan dindingnya sehingga perlu diantisipasi dengan mengganti atau menyumbat ( $p l u g$ ) sebelum tube tersebut bisa menggangu aktivitas produksi dan menggangu kualitas produk.

Namun secara keseluruhan keadaaan tube dari heat exchanger tersebut masih dalam keadaan baik dan layak untuk tetap memproduksi, tetapi harus dilakukan preventive maintenance secara berkala agar tube yang sudah terdapat indikasi cacat sebesar 41-60\% tidak pecah dan dapat menggangu aktivitas produksi. Berdasarkan Gambar 11, dibawah ini adalah hasil persentase dari hasil pemeriksaan tube secara keseluruhan dari heat exchanger EA-110. Berikut adalah persentase dari hasil pemeriksaan tube heat exchanger unit EA-110 secara keseluruhan yang terdapat pada Gambar 12.

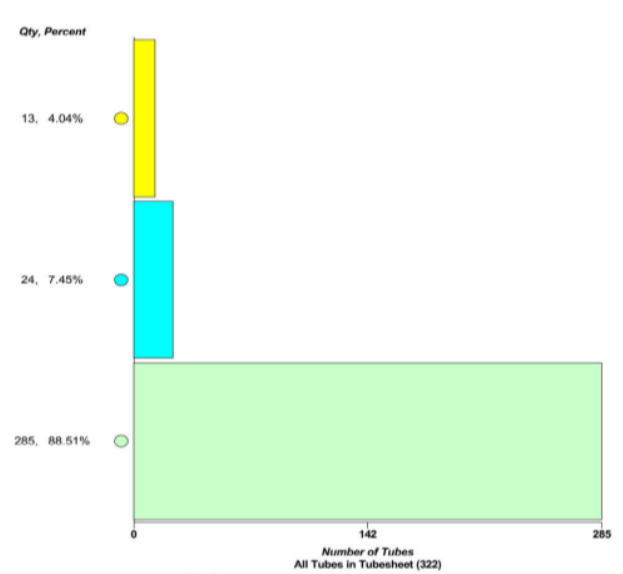

Gambar 12. Diagram pemeriksaan keseluruhan tube

Berdasarkan Gambar 12, kondisi tube dari heat exchanger EA-110 yang termasuk ke dalam klasifikasi cacat 1 sebesar $88,51 \%$ atau sebanyak 285 tube, rata-rata tube tersebut masih dalam keadaan baik. Lalu ada 24 tube atau 7,45\% yang termasuk ke dalam klasifikasi cacat 2 yaitu sebesar $21-40 \%$, tube-tube tersebut sudah dalam keadaan tidak baik lagi karena sudah mulai mengalami pengurangan ketebalan dinding yang perlahan-lahan membesar. Setelah itu ada 13 tube atau 4,04\% yang termasuk ke dalam klasifikasi cacat 3 yaitu sebesar 41 $60 \%$, tube yang mengalami pengurangan ketebalan dinding seperti ini sudah memasuki fase peringatan berbahaya karena dapat saja sewaktu-waktu pecah dan menggangu aktivitas produksi.

\section{B. Pengamatan Metalografi}

Berdasarkan Tabel 2, heat exchanger unit EA-110 tersebut memproduksi bahan kimia yaitu Ethylene. Ethylene merupakan salah satu jenis senyawa hidrokarbon yang memiliki rumus kimia $\mathrm{C}_{2} \mathrm{H}_{4}$, nama lain berdasarkan IUPAC (International Union of Pure and Apllied Cheimistry) adalah Etena. Senyawa tersebut termasuk dalam jenis alkena, yaitu senyawa hidrokarbon yang memiliki ikatan karbon rangkap $(\mathrm{C}=\mathrm{C})$ paling sederhana. Senyawa ini memiliki berat molekul sebesar $28,05 \mathrm{gram} / \mathrm{mol}$, densitasnya sebesar $1,178 \mathrm{~kg} / \mathrm{m}^{3}$, berwujud gas, mudah terbakar, tidak berwarna pada kondisi lingkungan normal serta berbau segar atau musky. Pengamatan metalografi ini dimaksudkan untuk mendapatkan gambaran struktur mikro permukaan dari spesimen ASTM A 334 Gr. 1 yang mengalami pengurangan ketebalan dinding tube akibat kegiatan produksi. Hasil pengamatan metalografi pada sample material tube dapat dilihat pada Gambar 13.
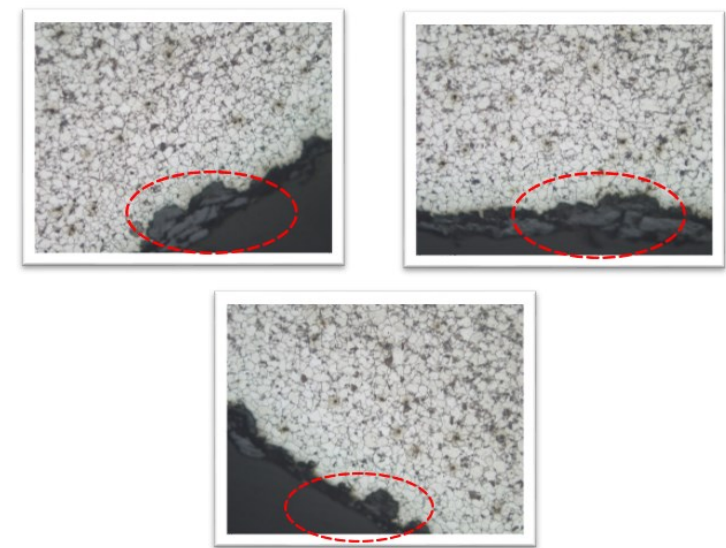

Gambar 13. Hasil pengamatan metalografi pada tube

Hasil dari struktur mikro pada sample tube menujukkan bahwa tube tersebut mengalami korosi seragam pada bagian permukaan dalam dari tube tersebut. Korosi seragam tersebut berada pada satu titik tertentu dan ditandai dengan adanya rongga-rongga pada permukaan logam, seperti yang ditunjukkan pada lingkaran merah.

Supaya lebih jelas melihat efek korosi pada tube, kita akan membandingkan hasil metalografi pada material tube yang terkorosi dengan mateial tube setelahh dilakukan preparasi. Berikut adalah hasil pengamatan metalografi pada material ASTM A 334 Gr. 1 yang akan dibandingkan dengan hasil pengamatan sebelum dilakukan preparasi dan sesudah dilakukan preparasi yang akan ditunjukkan pada Gambar 14. 


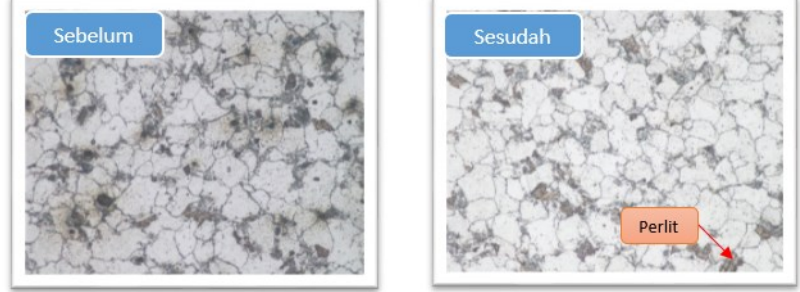

(a) Hasil pengamatan dengan pembesaran sebesar 500x
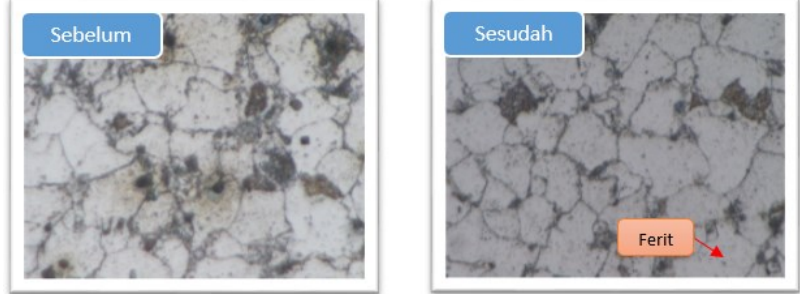

(b) Hasil pengamatan dengan pembesaran sebesar 1000x

Gambar 14. Hasil perbandingan antara pengamatan metalografi sebelum dilakukan preparasi dan sesudah dilakukan preparasi

Dari hasil perbandingan pengamatan metalografi tersebut dapat disimpulkan bahwa material ASTM A 334 Gr. 1 mulai terkorosi sedikit demi sedikit, itu dibuktikan dengan adanya titik-titik korosi yang terdapat pada Gambar 14 pada material uji sebelum dipreparasi. Indikasi tersebut bisa disebabkan oleh waktu penggunan yang cukup lama dan material tersebut digunakan untuk mengaliri bahan kimia yang seperti apa. Kandungan yang terkandung pada senyawa etilen itu menunjukkan bahwa, tingkat keasaman yang lumayan besar dan dengan jangka waktu penggunaan yang lama serta dengan adanya sisasisa produksi yang mengendap (deposit) bisa menyebabkan material tersebut mulai mengalami korosi pada dinding-dinding tube.

Korosi yang terjadi pada tube tersebut berdasarkan pada hasil pengamatan metalografi yaitu berupa korosi seragam. Korosi seragam ini terbentuk karena adanya deposit yang cukup tebal pada dinding tube. Deposit yang terbentuk tersebut tentunya dapat menghambat proses perpindahan panas dari luar pipa menuju ke dalam sebagai media atau fluida yang dipanaskan. Akibatnya secara teori, dapat meningkatkan temperatur hingga melampaui temperatur desain maksimum tube, sehingga dapat menyebabkan tube over heating walapun belum merubah struktur mikro.

\section{Pengujian Kekerasan Metode Brinell}

Proses ini bertujuan untuk mengetahui nilai kekerasan dari material ASTM A 334 Gr. 1 pada spesimen yang diuji dengan membandingkan dari nilai kekerasan sesungguhnya yang terdapat pada standar ASTM A 334 Gr. 1. Nilai kekerasan yang terdapat pada standar tersebut akan ditunjukkan pada Tabel 3.
Tabel 3. Nilai kekerasan maksimum pada material ASTM A 334

\begin{tabular}{ccc}
\hline Grade & Rockwell & Brinell \\
\hline 1 & B 85 & 163 \\
3 & B 90 & 190 \\
6 & B 90 & 190 \\
7 & B 90 & 190 \\
8 & $\ldots$ & $\ldots$ \\
11 & B 90 & 190 \\
\hline
\end{tabular}

Dari Tabel 3 kita dapat ketahui bahwa nilai kekerasan maksimal dari material ASTM A 334 Gr. 1 adalah sebesar 163 HB. Setelah kita mengetahui nilai kekerasan maksimumnya, lalu kita akan membandingkan hasil pengujian kekerasan pada spesimen benda ujinya dengan nilai kekerasan maksimumnya. Hasil pengujian kekerasan pada material ASTM A 334 Gr.1 menggunakan metode kekerasan brinell dapat dilihat pada Tabel 4.

Tabel 4. Hasil pengujian kekerasan menggunakan metode brinell

\begin{tabular}{lccccccc}
\hline No & Beban & $\begin{array}{c}\mathrm{d} 1 \\
(\mathrm{~mm})\end{array}$ & $\begin{array}{c}\mathrm{d} 2 \\
(\mathrm{~mm})\end{array}$ & $\begin{array}{c}\mathrm{d} \\
\text { rerata }\end{array}$ & $\begin{array}{c}\mathrm{d} \text { rata- } \\
\text { rata }\end{array}$ & $\mathrm{HB}$ & $\begin{array}{c}\mathrm{HB} \\
\text { rata- } \\
\text { rata }\end{array}$ \\
\hline 1 & & 0,73 & 0,73 & 0,73 & & 146,149 & \\
2 & & 0,75 & 0,75 & 0,75 & & 138,283 & \\
3 & 62,5 & 0,74 & 0,74 & 0,74 & 0,738 & 142,136 & 142,970 \\
4 & kgf & 0,73 & 0,73 & 0,73 & & 146,149 & \\
5 & & 0,74 & 0,74 & 0,74 & & 142,136 & \\
\hline
\end{tabular}

Hasil tersebut diperoleh dengan memperhatikan parimeter-parimeter ujinya, yaitu dengan melakukan pembesaran 70x dan dengan diameter indentor sebesar 2,5 mm. Lalu temperatur ruang ujinya sebesar $25^{\circ} \mathrm{C}$ dan kelembaban (RH) sebesar 67\% RH. Berikut adalah titik pengujian kekerasan metode brinell pada material ASTM A 334 Gr. 1 yang akan ditunjukan pada Gambar 15 .

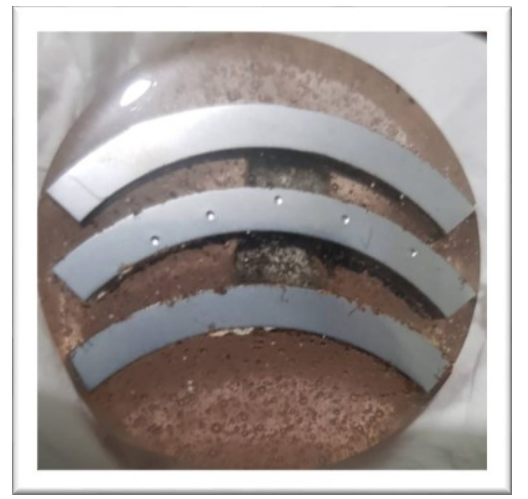

Gambar 15. Beberapa titik pengujian kekerasan pada material ASTM A 334 Gr. 1 
Proses pengujian pada spesimen yang akan diuji itu terdapat 5 titik pengujian, titik pengujian pertama mendapat nilai kekerasan sebesar 146,149 HB lalu pada titik yang kedua diperoleh nilai kekerasan sebesar 138 , $283 \mathrm{HB}$. Setelah itu, nilai kekerasan pada titik pengujian yang ketiga sebesar 142,136 HB, selanjutnya pada titik pengujian yang keempat diperoleh nilai kekerasan sebesar 146,149 HB. Dan titik pengujian yang kelima atau yang terakhir memperoleh nilai kekerasan sebesar 142,136 HB. Hasil dari kelima nilai kekerasan tersebut dirata-ratakan sehingga memperoleh nilai kekerasan sebesar 142,970 HB. Untuk lebih jelasnya, hasil pengujian kekerasan pada setiap titik pada material ASTM A 334 Gr.1 tersebut dapat dilihat pada Tabel 5.

Tabel 5. Hasil nilai kekerasan pada mateial ASTM A 334 Gr. 1 setiap titik

\begin{tabular}{ccc}
\hline $\begin{array}{c}\text { Titik } \\
\text { Pengujian }\end{array}$ & HB & HB rata-rata \\
\hline 1 & 146,149 & \\
2 & 138,283 & \\
3 & 142,136 & 142,970 \\
4 & 146,149 & \\
5 & 142,136 & \\
\hline
\end{tabular}

Dari hasil pengujian yang sudah dilakukan, bahwa nilai yang diperoleh dari spesimen yang duiji lebih kecil dari nilai maksimum kekerasan pada material ASTM A 334, yaitu 142, $970 \mathrm{HB}<163 \mathrm{HB}$. Hasil tersebut menunjukkan bahwa terjadinya penurunan nilai kekerasan pada spesimen uji akibat dari lamanya waktu pemakaian tube tersebut dan ditemukannya korosi seragam pada dinding tube yang disebabkan oleh deposit dari sisa hasil produksi.

\section{KESIMPULAN}

Berdasarkan hasil pemeriksaan pada bab 4 dan hasil pengujian kekerasan brinell, maka diperoleh kesimpulan dari hasil analisis kerusakan tube heat exchanger unit EA-110 pada PT. Chandra Asri Petrochemical menggunankan metode NDT (Remote Field Testing) adalah sebagai berikut :

1. Total tube yang diperiksa pada heat exchanger EA110 berjumlah 322 tube dengan 285 tube yang memiliki klasifikasi cacat sebesar 0-20\%, 24 tube yang memiliki klasifikasi cacat sebesar $21-40 \%$, dan 13 tube yang memiliki klasifikasi cacat sebesar 41$60 \%$.

2. Tube yang memiliki klasifikasi cacat sebesar $0-20 \%$ kondisnya masih sangat baik dan tidak ditemukan masalah yang berarti sehingga aman untuk tetap dipertahankan.

3. Tube yang memiliki klasifikasi cacat sebesar $21-40 \%$ kondisinya masih baik namun sudah mengalami pengurangan ketebalan tube dan seiring berjalannya waktu akan bertambah besar pengurangan ketebalan dindingnya.

4. Tube yang memiliki klasifikasi cacat sebesar 41-60\% kondisinya sudah tidak baik dan harus menjadi perhatian agar tube tersebut tidak mengalami kebocoran sewaktu-waktu sehingga menggangu aktivitas produksi.

5. Berdasarkan hasil pengamatan struktur mikro, korosi yang terjadi pada tube heat exchanger unti EA-110 adalah korosi seragam. Korosi ini disebabkan oleh terbentuknya deposit pada dinding dalam tube yang mengakibatkan terhambatnya proses perpindahan panas.

6. Berdasarkan hasil pengujian kekerasan dengan menggunakan metode Brinell diperoleh nilai kekerasan rata-rata pada spesimen uji adalah 142,970 HB. Hasil tersebut adalah lebih rendah dari nilai kekerasan maksimum dari material ASTM A 334 Gr. 1, yaitu sebesar $163 \mathrm{HB}$.

\section{UCAPAN TERIMA KASIH}

Terima kasih kepada PT. Wigati Teknikindo yang telah memberikan dan menganalisis data-data pengujian remote field testing. Serta kepada Bapak Mario yang telah membantu dalam pengujian metaolgrafi dan dalam pengujian kekerasan brinell pada material.

\section{REFERENSI}

[1] E. Wulandari, Anailsa kegagalan tube drain superheater pada heat recovery steam generator (HSRG), S-1 skripsi, Institut Teknologi Sepuluh Nopember, Surabaya, 2016.

[2] H. Sunandrio dan Sutarjo, Serangan korosi sumuran pada tube heat exchanger di kilang pengolahan minyak, M.P.I., vol. 8, no. 3, 2014, pp. 93-100.

[3] R. Sony Endardo P., Analisis kegagalan bend tube preheater pada heat recovey steam generator, $S-1$ skripsi, Institut Teknologi Sepuluh Nopember, Surabaya, 2017.

[4] Muchammad, Analisis penurunan performa heat exchanger stabilizer reboiler $011 \mathrm{E} 120$ di PT. Pertamina Refinery unit IV Cilacap, Momentum, vol. 13, no. 2, 2017, pp. 72-77.

[5] H. Rusjdi, E. Prabowo, W. Rian, Analisis pepindahan kalor high pressure heater PLTU Banten 3 Lontar unit 1, Jurnal Power Plant, vol. 4, no. 3, 2016, pp. 122-210.

[6] E. Febriyanti, Analisis kerusakan pipa baffle pada sistem heat exchanger suatu proses transfer panas, Majalah Metalurgi, vol. 28, no. 3, 2013. Pp. 185194.

[7] I. Syahri Cebro dan Sariyusda, Analisis korosi pada heat exchanger E-4512 PT. Arun NGL Co, Jurnal Polimesin-Politeknik Negeri Lhoksumawe, vol.1, no. 1, pp. 50-60.

[8] H. Sadek, Electromagnetic testing classroom 
training book, The American Society for Nondestructive Testing, Inc, 2006.

[9] W. Hendroprasetyo, Training hand out eddy current testing, NDE Centre, 2018.

[10] Ibrahim, M. Rizal, Analisis kegagalan material baja karbon ASTM a 179 dan SS 3161 pada tube heat exchanger 09-E-105 PT Petrokimia Gresik, Jurnal Teknik Material dan Metalurgi Institut Teknologi Sepuluh November, Vol 1, No. 1, 2013, 50-60 